\title{
DOI https://doi.org/10.24195/spj2310-2896.2019.4.20
}

\author{
Яровицька Наталя Анатоліївна \\ кандидат філософських наук, \\ доцент кафедри суспільно-гуманітарних дисциплін \\ Харківського національного університету будівництва та архітектури \\ вул. Сумська, 40, м. Харків, Україна \\ Мельник Емілія Анатоліївна \\ кандидат філософських наук, доцент, \\ доцент кафедри правових наук та філософії \\ Вінницького державного педагогічного університету \\ імені Михайла Коцюбинського \\ вул. Острозького, 32, м. Вінниця, Україна
}

\section{«Я І НІЩО»: СИМВОЛІЧНІСТЬ РЕАЛЬНОГО АБО РЕАЛЬНІСТЬ СИМВОЛІЧНОГО (ЗА МАТЕРІАЛАМИ ТВОРЧОСТІ Г. ПІНТЕРА)}

\begin{abstract}
Актуальність. Світ розуму та почуттів у світоглядній парадигмі мав зустріч з одним із висловів німецького письменника Й. Гете, який є автором важливої сентенції, суть якої розкривається в тому, щьо набуття повноти (всього) для суб'єкта, історії, часу, мови неможливо без проходження стану «ніщуо».

Мета. Представити абсурд як філософську платформу «Зустріч-Подія», яка має травматичну спрямованість, де герої, їх діалоги є лише фоном, мовним «мереживом», створюючи кокон долі для персонажів.

Методи. Літературна скарбниця сучасності відображсає символічний вимір мови: від техніки промовляння до опису подї мовного намарування, яке відбувається завдяки вмілому нагромадженню багатьох смислових навантажень у мовних конструкціях (Ж. Лакан, Р. Барт, Ж-П. Сартр).

Результати дослідження. Для Г. Пінтера в його літературних творах нема усвідомленого начала та кіния, адже кінець може стати прологом або початком до дотику з реальністю; приховане виявляє реальне, а реальність супроводжує своєю наявністю простір утаємниченого, завдяки розгортанню самої вистави-реального. Індивід, зіткненням із собою, завдяки Ніщу, відкриває свою сутність, якою б принизливою чи бездоганною вона не була. Ця зустріч абсурдна за природою, втім одночасно вона народжує альтернативні сенси, незважаючи на те, щуо містить у собі ядро травми. Обертання навколо ичих станів («повноти і ніщо») формулює та демонструє творчий літературний доробок одного з Нобелевських лауреатів англійського прозаїка та письменника Гарольда Пінтера. Звернення до порожнечі, яка глибше та повніше за самий наповнений зміст речі, можливість приєднатися до дискусії та пошуку витоків особистого забуття через розкриття принад фрагментарності, мозаӥчності буття героїв - основа сюжетних перехресть робіт письменника («Сторож», «Зрада» та інші).
\end{abstract}

Ключові слова: абсурд, Ніщо, символічне буття, сенс, мовна конструкиія.

Те, що перебуває перед нами безпосередньо, це лише вступ до того, що ховається від нас десь там у далині. Хосе Ортега-і-Гассет «Роздуми про Дон Кіхота»

Вступ. Відомий німецький мислитель, літератор, філософ сучасності М. Гайдеггер якось зазначив, що людина, перебуваючи в полоні долі, жадібно намагається зрозуміти таємничість, що уособлюються в різноманітних світоглядних феноменах людської іпостасі: турбота, любов, зрада, загубленість, самотність, сенс, буття, потворність, час [7; 8; 11]. Насправді, для людського «Я» підкорити всі ці явища, опанувати та збагнути їхню природу не є великою 
насолодою, але водночас зачаровує та бентежить безпосередньо таємниця їх існування у власній свідомості індивіда як прояву Всесвіту $[7 ; 11]$. Тому своєрідна місія - розкрити таємничість та ризик, який супроводжує дослідника на цьому шляху, окреслює горизонт передчуттів, які досліджував Нобелевський лауреат 3 літератури 2005 року англійський прозаїк, письменник Гарольд Пінтер, збуджуючи неочікуваними, а інколи провокативними висновками читача, глядача. Його творчість - поліфонія речей, предметів, станів, роздумів; своєрідна безодня реальності, перебування в якій є абсурдною за своєю суттю, і саме в цьому полягає її шарм, смак та зняття обмежень.

Мета та завдання полягають у розкритті та демонстрації дії головних персонажів у модусі трьох наявних культурних дихотомій, а саме: дія / імітація (або бездіяльність); реальність / ілюзія; явне / приховане. Означені стратегії розкривають сутність та всю безпорадність героїв, їхню розірвану, спаплюжену свідомість, в природі якої терпимість межує з невдоволенням, агресією, натиском у діалогах, що проявляється як абсурдний життєдайний ковток у безодні реальності.

Абсурд - межа реального та символічного, створена даним феноменом. Спонтанність та випадок формують передумови для спотворення та розквіту думок головних героїв, їхніх бажань, надмірності, деформації або, навпаки, читачеві випадає унікальна нагода здійснити особисту метаморфозу духу завдяки внутрішньому роз'ятренню персонажів. Отже, герої провідники читача, які наповнюють реальність символічними барвами, де читач натомість залишає символічному світу дивакуватий шматочок реального.

Методи дослідження. Безпосереднє занурення у літературні скрижалі того чи іншого автора неможливі без теоретичного обгрунтування основних визначень у філософсько-літературній аналітиці. Поняття «поетика» має грецьке походження та визначається як теорія поезії; наука, що вивчає поетичну діяльність, їі походження, форми та значення, в широкому аспекті закони літератури взагалі. Отже, термін «поетика» використовується в трьох значеннях:

- поетика як «літературність», перетворення мови на поетичний твір та систему засобів, прийомів, завдяки яким це перетворення здійснюється;

- поетика як вивчення не тільки речових, але й структурних моментів художнього тексту;

- поетика як розділ загальної естетики, який не обмежується винятково сферою літератури, а постає центральним ядром мистецтва, досліджень 3 філософії літератури та гуманітарних візій лінгвістичного простору.

Історична генеза поетики пов'язана 3 фігурами античності, середньовіччя, класичного періоду, етапів постсучасного дискурсу. Сучасні дослідники активно розкривають один з глибинних напрямів поетики - поетику абсурду. В цьому аспекті важливо проаналізувати специфічний характер поняття «абсурду», який уособлює кореневе живлення літературного мистецтва Гарольда Пінтера. Так, французький структураліст та семіотик Ролан Барт у своїй статті «Література та сенс (значення)» ототожнює поняття «абсурду» та «нонсенсу», називаючи їх «не-сенсом» або «протисенсом», та протиставляє їх сенсу, з одного боку, та «поза-сенсу»з іншого [8; 11]. Поняття абсурду в інтерпретації Ж. Дельоза є субстанцією, замкненою у собі. Дослідники I.А. Попова-Бондаренко, I.А. Рижкова вважають, що абсурд створює складну художню систему, яка спирається на принцип гри та явище парадоксу [2].

Розвиток ідей абсурдизму в літературі в ХХ ст. має свою специфічну спрямованість, а саме: 50-60-ті роки XX ст. позначились бурхливим розвитком експериментів, пошуків, які пов'язані iз загальною назвою «театр абсурду»: новітня драматургія, мовні пошуки шокували експериментами у техніці виконання, образах героїв. Бунт проти традиційних цінностей та досвід катастрофи Другої Світової - ось спадщина, з якою потрібно було навчитися жити, опанувати

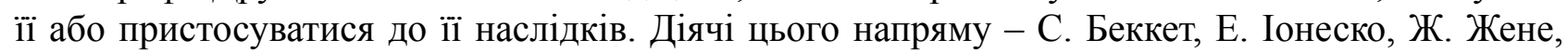
Г. Пінтер $[2 ; 3 ; 5 ; 6]$.

Гарольд Пінтер один 3 найвпливовіших драматургів Великобританії другої половини XX ст. Його театр формується у головах персонажів: народжується театральний світ, перебування в якому занурює читача (глядача) у тенета мовних ігор, примарної цінності спілкування, 
кризи комунікації, сумніву щодо сприймання себе, прояву особистої безпорадності. Поняття «абсурдистський» пов'язане насамперед з французьким театром повоєнних років. Саме він стає колискою народження нового жанру - драми абсурду, в просторі якого постають екзистенційні, світоглядні виміри людського буття, обпеченого досвідом війни, а саме - спустошеність, відчуження, забуття, буденність існування, імітація життя, його заміщення другорядними присмаками, ворожість ставлення суб'єкта до навколишнього світу та оточуючих. Абсурдисти своєрідним чином трактували категорію трагічного: герої «анти-драми» не усвідомлювали імітування власного життя, своєї безпорадності; вони не бажають дотику з якістю, яка фіксує героя як зайвого, не усвідомлюють відсутності сенсотворення свого життя, власної алієнації. Як зазначає дослідник А.С. Малій, драматурги школи абсурду неординарно відображали комічні аспекти, поєднуючи «трагедію людського існування з фарсом та карикатурою» [3, с. 50]. На теренах театральної спадщини Великобританії абсурдистська драма представлена такими іменами, як Ніколас Сімпсон, Джеймс Сондерс, Гарольд Пінтер. Г. Пінтер стає автором важливого прийому конструювання сценічного діалогу - це прийом допиту, «який маркує акт психологічної агресії: динамічність процесу постановки запитань, більшість яких має звинувачувальну конотацію» [3, с. 51], не дає жертві осмислити особисті висловлювання, в яких проглядаються смислові розриви та суперечливість тверджень. Народжується відчуття затхлості від присутності всіх головних героїв у колі сюжетної лінії, та при цьому звільнитися від них немає ніякої можливості; це той випадок, про який зазначав відомий дослідник театру абсурду Мартін Есслін [9], що «піти для діючих осіб так само неможливо, як і залишитися» [9, с. 100]. Антипатія один до одного уособлює формулу «безкінечності закінчення», «гри в якості фарсу та драматизму парадоксальності», що в творах Г. Пінтера отримує нове коло інтерпретацій можливостей для літературно-філософської рефлексії.

Результати. Якісно новий рівень драматургії Г. Пінтера спостерігається у п’єсі «Сторож» (1960), у якій основою стає особлива риса -ідея розгубленості, безпорадності, самовпевненості, тремтячої німоти героїв драми. І це стосується не тільки головного персонажа - бродяги Девіса, у якого навіть ім'я приховано у шухляду підробних документів, а й братів Астона і Міка, в чиїй домівці він мав надію отримати притулок, дах над головою, навіть 3 дірявою покрівлею та прив'язаним до даху цебром, створити основу, підгрунтя своєї загубленості. Нема ніяких братерських почуттів, взаємин між братами: Мік завжди з'являється на сцені за відсутності Астона, а щойно той приходить додому, Мік поспішає зникнути. Відома бінарна опозиція «агресор / жертва», яка притаманна для гуманітарної рефлексії «Сторожа» [5], демонтується та розкривається дія центральних персонажів у модусі трьох наявних культурних дихотомій, а саме: дія / імітація (або бездіяльність); реальність / ілюзія; явне / приховане.

Головні герої здійснюють безліч дій: лагодять механічні прилади, шукають чоботи, в гармидері пробують знайти Девісу ліжко, яке вільне від лахміття. Пишуть прожекти у вигляді ремонту різноманітного приладдя, розширення кімнати, ремонту покрівлі та кімнат. Втім, все це стає пилом та ілюзорністю буття. Лише статуя Будди, яка дивним чином опинилася на цьому дні, сприймається як розрив «шаблону», як пунктирна цятка, що відважується зголоситися в безодні і, таким чином, спробувати допомогти персонажам відшукати шлях до самого себе, абсурдний, як і самі герої. Втім, ця статуетка постала лише однією з мінливих невиразностей життя діючих осіб, тому під кінець сварки Астона і Девіса, новий знайомий розбиває фігурку Будди. Може невипадковим є розміщення саме цього релігійного мислителя, адже буддизм сповіщає у своєму каноні про страждання життя, тому вона посилює, акцентує напевно і цей контекст, адже існування героїв дійсно можна вважати, як страждання самих від себе. Сам Г. Пінтер відмічав, що «коли комічне і трагічне переплетені, більшість глядачів віддають перевагу комічному, таким чином, вони зможуть дозволити собі не помічати останнього» [4, с. 87].

Отже, абсурд - феномен не стільки логічного підпорядкування, скільки символічного виміру. Постаті братів не менш яскраві. Вони створюють атмосферу особистої неприсутності в просторі іншого, перетинаються між собою неявно, навіть ірраціональним засобом. Обидва конструюють свою уяву щодо домівки та присутніх у цьому приміщенні, як мінливого і уявного 
острівка псевдо-стабільності, завдяки залученню до діалогу незнайомця. Бродяга Девіс, немов би «поржавілий ключ на зв'язці з іншими брудними й недотепними речами, який давно знаходився десь у шухляді, покритий пилом, а тепер ним намагається знайти бодай якусь шпарину, щоби відкрити дверцята будівлі. Астон та Мік шукають можливість додати до своєї присутності (з особистою вигодою, якщо вийде) наявний портрет Девіса, тому вважають його сторожем, фахівцем-декоратором, ремісником, людиною дії. Та всі три герої мають внутрішню надмірність: вони хворобливо самовпевнені в собі, внутрішнє «Его» виявляє хибні вади персонажів, що розкривається в стилістиці мови («немає поряд чорномазих», «у нього не все добре з головою», «ти знаєш, з ким розмовляєш, я з такими людьми знався», «не можу спати на холоді») [5].

Девіс - неординарна фігура, він створює абсурдність не свого перебування в чужому місці, а встановлює своєю поведінкою межі господарів домівки. І коли вони стикаються 3 таким явищем, гуртуються з метою викинути Девіса на смітник, адже він відкрив не те, на що були спрямовані сподівання та надії кожного з братів, тому в останній сцені брати перетинаються між собою і навіть посміхаються, оформлюючи системи внутрішнього коду «свій / чужий». Так, вони, щоб не було - все ж таки «свої», а бродяга - прибулець, чужак, який вносить незрозумілі виклики стосовно їхнього життя, облаштування кімнат, прибирання приміщення. Діловито й завзято починає наповнювати чужий простір своєю сутністю. Кожен став ілюзією самого себе - у планах, у мріях нездійсненного: добудувати сарай (Астон), відремонтувати житло (Мік), забрати свої документи в Сідкапі (Девіс), знайти черевики з широкими носками (Девіс) - і все це, напевно, залишиться як «присутність відсутності». Просвіт маленького дива знаходить свій прояв лише у тому, що в кінці п'єси у цеберко стала повільніше збиратися вода 3 дірявого даху, можливо, Астон зашпаклював нарешті дірки, припускає бродяга. Мрія Девіса про годинник, якого нема в домівці у братів: «Якщо знаєш, котра година, почуваєш себе вільно» [5, с. 156], виглядає доволі іронічно, особливо, коли їі виголошує безхатько. Але людина не згодна з тавром зайвої, тому всією міццю пробує зачепитися за речі «нормальності»: мати кишенькові гроші, мати годинник, костюм, чисту постіль, спати на ліжку без протягів. Девіс чіпляється за те, що формує життєву повсякденність людини, яка спроможна на волю, активність. Натомість «Подія-Зустріч» наштовхує Девіса на Астона, який нездатний взагалі ні на що: мрійник, непрацюючий «нахаба-псевдоестет». Назва п’єси виявляє символічну місію персонажів: кожен з героїв немов би пристосовується бути невидимою «тінню» іншого, 3 метою певного контролю дій, співставленням вчинків дійової особи з особистим баченням реальності, спостерігачем: Девіс контролює Астона, Мік Девіса, брати доповнюють разом своєю відсутністю один одного, адже коли в кімнаті з'являється Мік, Астон ще не повернувся з міста додому, і навпаки.

Велика заслуга майстра слова Г. Пінтера в залученні мовного навантаження, яке розкриває специфіку стилістичних прийомів, що демонструється в п'єсах англійського автора поетики абсурду.

Отже, аналізуючи гуманітарний корпус досліджень у просторі мовного дискурсу, літературної специфіки, постає нагальна потреба вийти за межі суто філологічного наративу та залучити ряд фундаментальних концепцій, які загадковим чином відтворюються на тлі текстуального. Поетика Г. Пінтера не має єдиного методологічного підходу, вона багатошарова, поліваріативна за своєю суттю: герої борсаються в імітаціях, симулюючи своє життя, адже вони відчужені від самих себе. В цьому аспекті заслуговує на повагу теоретична спадщина французького структураліста Жана Лакана [10]. Так, феномен суб'єкту розкривається наступним чином: суб'єкт відчужений від свого буття - його історія має витоки з ніколи незавершуючого присвоєння особистого проективного образу [8, с. 282], а також для суб'єкта притаманне відчуження в символічному регістрі (модусі, рівні) - в семіотичному полі, йому не притаманному, гетерогенному (ворожому) та попередньому, в якому несвідоме уособлює дискурс Іншого (герої п’єси «Сторож»). Якщо своїм буттям суб'єкт зобов'язаний визнанню з боку Іншого, натомість його доля - процес знову й знову присвоювати власне своє відчужене буття (бродяга Девіс, брат Мік). У боротьбі за визнання зі сторони Іншого розкриваються (проявляються) бажання, 
свідомість, страх, відчуження суб'єкту: адже не тільки моє існування залежить від Іншого, а й моє бажання також народжується в Іншому [8]. В результаті суб'єкт повинен не тільки присвоювати постійно свій особистий проективний образ, але й бажання як бажання Іншого, так і власну істину мовою Іншого (яка говорить мовою Іншого).

Положення (перебування, існування) суб'єкта в мові Іншого формує дві парадигми-порожню та повну. Ж. Лакан залучає класифікацію М. Гайдеггера через дихотомію мови та балаканини. Слід зазначити, що такий розподіл має свою реалізацію у п'єсі «Сторож»: повна промова наповнена сенсом, а тому істина, на думку Лакана, ближче за все підходить до висловлювання бажання та формулює символічний вимір мови; пуста промова - уявна - в ній суб'єкт від свого бажання відчужений [8, с. 283]. У п’єсі «Сторож» Г. Пінтер часто використовує в діалогах героїв мовні повтори, тривалі паузи, уточнення, які насичують образи додатковою напругою у відносинах між персонажами. Тому доречно звернутися до символічного наповнення поняття «повтору».

Саме свою теорію символічного Ж. Лакан доповнює поняттям «повтору». Так, повтор спрямований не у минуле, а у майбутнє; воно не тільки уособлює символізацію несимволізованої травми речі (статуетка Будди; несправна газова плита; портер в товстому кухлі, але Астон п'є лише $з$ тонкого), втім, містить у собі вимір новизни, неочікуваного, не-теперішнього. Акти повторення зв'язують символічне з реальним; таким чином, «те, що повторюється, обов'язково виникає знову й знову, ніби випадково» [8, с. 283].

Отже, феномен абсурду в п’єсах Пінтера уособлює ідею «Зустрічі-Події», яка за своєю природою є глибоко травматичною. Вона ставить суб'єкта в ситуацію, яка спрямована на обмеженість, їі оголеність, робить вразливою свідомість персонажа. Індивід пригадує все те, що бажав би забути (спогади Девіса про залишений у невідомого паспорт п'ятнадцять років тому, участь у штовханині-бійці тощо). Відомий представник німецької комунікативної філософії О.Ф. Больнов [1] визначав поняття Зустріч як екзистенційну категорію, до основних характеристик якої належить «наштовхування людини на непередбачувану в ній самій реальність, яка для неї є доленосною та кардинально відрізняється від того, що людина очікувала» [1, с. 168].

Особливим складником у роботах Г. Пінтера виступає просторова обмеженість у вигляді кімнати, яка уособлює тимчасовий, але прихисток, на думку, головних героїв. Втім, ясна річ, що даний прихисток - кімната - $\epsilon$ проявом симуляції, яка має своє продовження та наповнення у світі предметів інтер'єру, заповнюючи, таким чином, порожнечу свідомості у діючих осіб. Побутові предмети, які не працюють, нагромадження непотребу перетворює на смітник життя головних персонажів. Речі посилюють нестерпні умови повсякденного існування для дійових осіб. Навіть світло зникає та освітлює приміщення нерівномірно, а сполохами. Світ речей складає надлишковість прояву побуту: чашок, ложок, вкритого пилом ліжка, подушок, простирадла. Хаотичне нагромадження різноманітного мотлоху актуалізує безодню реальності, дієвість у бездіяльності, симуляцію життя. Побудовані всі умови для втечі з цього бункеру життя, але «екзистенційний» мотлох гасить намагання усіх на будь-які зміни мороком адаптації до цього засилля зайвого: речами, словами, мріями, що не здійсняться, незнайомими людьми. Окреслюється «замкнуте коло», перебування в якому можливо у дуеті театру-абсурду. Доленосна реальність, у самій людині, на зустріч з якою вона не очікувала, посилюється завдяки сенсам та наявності абсурду. Яким чином можна зазирнути в прихований світ власних думок та почуттів? Цей процес відтворюється за допомогою зіткнення фізичної реальності суб'єкту з ментальними структурами підсвідомого. В результаті народжується картина хаотичності, невизначеності людського «Я». Предмети підміняють собою стан людини, заміщають травми реальності, спотворюючи побутову сторону життя героїв. Але в цьому полягає головний парадокс: герої п’єси не формулюють для себе стан спустошення, вони знаходять межу між собою і світом побуту і вже не мають нагоди долати ці перешкоди: реальність стає ілюзорною (прожектом), як, наприклад, переймання безробіттям Астона, а абсурд постає наявним буттям, природною тканиною, повітрям для людини: і вже нема питань, адже існує те, чим можна дихати. 
Набуває важливості і той факт, що Г. Пінтер у п’єсі «Сторож» актуалізує соціальну проблематику, яка пов'язана з відношенням Девіса до оточуючих його робітників - вихідців з інших країн. Він постійно запитує про «чорномазих», «не англійців», греків, поляків, які винні у втраті робочого місця Девісом. Свою гіперболізовану гідність, що зазнала атрофічної трансформації, бродяга Девіс ілюструє прикладами інтимного характеру; так, він розповів людині, з якою не був знайомий, що пішов від дружини через купу її невипраної білизни, яку дружина складала у корзину для овочів; згадував про своє негативне відношення до монаха у монастирі, коли Девіс прийшов за одягом [5]. Сценки побуту складають мозаїку затхлості, виснаження і дистанції, яка супроводжує читача до головних персонажів.

Отже, явне продовжує приховане, воно кричить у лоні потаємного, а виходячи на поверхню, робить дійових осіб ще більш вразливими та занедбаними. Герої «Сторожу» тримаються за абсурд, як життєвий слоган, якір, завдяки якому не потрібно спливати на поверхню реального світу. Безодня вабить більше, хоча кольори не яскраві, а тусклі: Г. Пінтер грає в тексті зі світлом та тінню, поступово залишаючи в сутінках одного бродягу, який продовжує вести діалог 3 Астоном, що зникає. Парадоксально, втім час перебування в просторі абсурду стає для героїв спасінням та роз'ясненням свого поневіряння. Навіть нема сумніву в тому, що дані персонажі ніколи не дадуть ладу в своїй кімнаті, не зроблять ремонт, не вивезуть на смітник увесь непотріб. Річ у тім, що персонажі доповнюються саме завдяки наявності гармидеру в їхній оселі: мотлох з купи поламаних предметів побуту розкриває інтенсивність псевдодій всіх учасників зустрічі. Купа сміття в домі - це сміття в свідомості, нездоровий стан, який актуалізується метафоричним засобом завдяки наявності в тексті розповіді перебування Астона в клініці для душевнохворих. Психічна неврівноваженість як допоміжний пунктир до більш глибинної травми неспроможності, що намагаються приховати в підсвідомості головні герої.

Висновки. Феномен «абсурду» - стан межі, провалля у безодню ілюзії, симуляції своїх дій, прояву нелогічних вчинків, які характеризуються категоричністю за своєю природою; вони бентежать оточуючих, але не визивають сумніву з боку тих, хто їх робить. Герої вживаються у роль провідників між світом буденності і світом прірви, вони знають код у вигляді феномену абсурду, за допомоги якого прориваються в світ реального, але перебуваючи там у статусі зайвих людей. Тому швидко повертаються назад «додому», де на їх чекає дірявий дах, цебро, куди стікає вода, не працююча газова плита, відсутність Світла, як в прямому, так і в переносному сенсі. Всім героям нема, куди йти, нема можливості терпіти один одного: абсурдність ситуацій трансформується у фатальність їхнього буття.

Відомий іспанський літератор та мислитель Х. Ортега-і-Гассет зазначав, що «бачити - не те саме, що дивитися» [4, с. 57]. Процес бачення - механічне спотворення реальності, роздратування дотиком, зустріччю з нею, натомість, коли людина дивиться, вона актуалізує «синтетичний зір», який вислизає з суто біологічного призначення особистості. Г. Пінтер створює умови для народження саме такого типу зору завдяки залученню поетики абсурду. Абсурд демонструє прояв реальності безодні як «тут-і-зараз», зіштовхує героїв, оголює наявність безодні в їхній сутності. Життєвий простір персонажів англійського прозаїка народжується завдяки особистому вибору, який вигляд він не мав би. Все знаходиться в середині нас: і тостер, який весь час ремонтує Астон, і цебро, що наповнюється водою із дірявої покрівлі, і мовчання рідних братів, які ігнорують один одного, і стосунки, що приречені в самому акті свого народження між Джері та Енн. Абсурд як смисл, що протиставляється логічній закономірності буття, і тому має, можливо, специфічний вигляд, який продовжується на рівні тілесного та ментального у героїв, не покидає відчуття дивності від того, що відбувається на наших очах.

Абсурд - категорія філософська, мовна, естетична, етична, світоглядна та має глибокий присмак іронії: «це все одно, що намагатися віднайти три лапи в кота» [4, с. 66]. Визначаючи Гарольда Пінтера лауреатом Нобелевської премії з літератури у 2005 році, Нобелевський комітет наголосив, що основний внесок англійського майстра слова пов'язаний з глибинним вмінням розкриття у п'єсах прірви між побутом (повсякденністю), рутиною життя та закритими просторами підсвідомості. Об'єднуючою ланкою є категорія «абсурду», яка миттєво 
актуалізує соціокультурне та світоглядне дно, в якому існують головні герої; вади реальності, що створюють передумови для посилення «повтору» симуляції стосовно себе та оточуючих; неспроможність заставити себе здійснити стрибок із небуття до простору буття. Коли дуже довго вдивлятися в безодню, вона тебе, врешті решт, спаплюжить - людина стає лише наявною фізично, втім морально та світоглядно вона із себе виробляє кокон, у який, немов би у панцир, загортається, змінюючи свої звички, ходу, пристрасті, прагнення. Це вже перевертень, зайва людина, насамперед для самої себе.

Таким чином, абсурд стає вихідною точкою-подивом перед життям: усі спроби пояснити та розв'язати дійсність руйнуються у безодні, тому що логічність аргументації вже є хибним інструментарієм, перепоною, коли буття «тут-і-зараз» обертається навколо нас і своїм існуванням заганяє у глухий кут усі підготовлені відповіді заздалегідь. Обличчя підсвідомого, що випливають на поверхню завдяки феномену абсурду, неочікувані, розхристані та зайві, а їхні власники обмежені та німі, хоча від їхніх балачок може здригатися навіть повітря. Втім, симуляція власного життя - це завжди пролог та епілог одночасно.

\section{СПИСОК ВИКОРИСТАНИХ ДЖЕРЕЛ}

1. Больнов Отто Фрідріх Зустріч. Першоджерела комунікативної філософії. Київ : Либідь, 1986. С. $157-172$.

2. Доценко Е. Г. Абсурд как проявление театральной условности. Известия Уральского государственного университета. 2004. № 33. С. 97-112.

3. Малій А.С. Особливості абсурдистської драматургії Гарольда Пінтера Вісник Київського національного університету імені Тараса Шевченка. Іноземна філологія. 2009. Вип. 42. С. 49-53.

4. Хосе Ортега-і-Гассет. Роздуми про Дон Кіхота. Київ : ДУХ І ЛІТЕРА, 2012. 216 с.

5. Пинтер Г. Сторож (пьеса, перевод А. Дорошевича) / Г. Пинтер Коллекиия (авторский сборник). Санкт-Петербург : Амфора, 2006. С. 147-226.

6. Пинтер Г. Предательство (пьеса, перевод Б.Носика, В.Харитонова) / Г. Пинтер Коллекция (авторский сборник).Санкт-Петербург: Амфора, 2006. С. 452-513.

7. Сартр Ж.-П. Объяснение к «Постороннему». Назвать вещи своими именами. Программные выступления мастеров западно-европейской литературы ХХ век. Москва : Прогресс, 1986. C. $92-107$.

8. 8.Современная западная философия. Энциклопедический словарь / под ред.: О. Хеффе, В. С. Малахова. Москва : Культурная революция, 2009. 392 с.

9. Esslin Martin. Language and Silence. Harold Pinter: Critical Approaches. London,1984. Pp. 34-59.

10. Macey D. Lacan in Contexts. New York : Verso, 1988. 324 p.

11. Sartre Jean-Paul Existentialism and Humanism. London : Methuen, 1970. 74 p.

\section{REFERENCES}

1. Bolnov Otto Fridrih Zustrich. Pershodzherela komunikativnoyi filosofiyi. [The primary sources of communicative philosophy]. Kiyiv: Libid, 1986. Pp. 157-172 [in Ukrainian].

2. Docenko E. G. Absurd kak proyavlenie teatralnoj uslovnosti. [Absurdity as a manifestation of theatrical conventions]. Izvestiya Uralskogo gosudarstvennogo universiteta. 2004. № 33. Pp. 97-112 [in Russian].

3. Malij A.S. Osoblivosti absurdistskoyi dramaturgiyi Garolda Pintera [Features of Harold Pinter's absurdist playwriting]. Visnik Kiyivskogo nacionalnogo universitetu imeni Tarasa Shevchenka. Inozemna filologiya. 2009. Vol. 42. Pp. 49-53 [in Ukrainian].

4. Hose Ortega-i-Gasset. Rozdumi pro Don Kihota [Reflections on Don Quixote]. Kiyiv: DUH I LITERA, 2012. 216 p. [in Ukrainian].

5. Pinter G. Storozh [The watchman] (p'esa, perevod A. Doroshevicha) / G. Pinter Kollekciya [Collection] (avtorskij sbornik). Sankt-Peterburg: Amfora, 2006. Pp. 147-226 [in Russian].

6. Pinter G. Predatelstvo [Betrayal] (p'esa, perevod A. Doroshevicha) / G. Pinter Kollekciya [Collection] (avtorskij sbornik). Sankt-Peterburg: Amfora, 2006. Pp. 452-513 [in Russian].

7. Sartr Zh.-P. Obyasnenie k «Postoronnemu» [Explanation to the "Outsider"]. Nazvat veshi svoimi imenami. Programmnye vystupleniya masterov zapadno-evropejskoj literatury XX vek. Moskva: Progress, 1986. Pp. 92-107 [in Russian]. 
8. Sovremennaya zapadnaya filosofiya. Enciklopedicheskij slovar [Modern Western philosophy. Encyclopedic Dictionary] / pod red.: O. Heffe, V. S. Malahova. Moskva: Kulturnaya revolyuciya, 2009. 392 p. [in Russian].

9. Esslin Martin. Language and Silence . Harold Pinter: Critical Approaches. London, 1984. Pp. 34-59. [in English].

10. Macey D. Lacan in Contexts. New York: Verso, 1988. 324 p. [in English].

11. Sartre Jean-Paul Existentialism and Humanism. London: Methuen, 1970. 74 p. [in English].

Yarovytska Natalia Anatoliivna

$\mathrm{PhD}$ in Philosophical Sciences,

Associate Professor of the Department of Publicly-Humanitarian Disciplines Kharkiv National University of Construction and Architecture 40, Sumskaya str., Kharkiv, Ukraine

Melnyk Emiliia Anatoliivna

Doctor of Philosophy, Associate Professor, Associate Professor of Department of Legal Sciences and Philosophy Vinnytsia Mykhailo Kotsiubynskyi State Pedagogical University 32, Ostrozhskyi str., Vinnytsia, Ukraine

\section{«I AND NOTHING»: SYMBOLISM OF REALITY OR REALITY OF SYMBOLIC (ON THE MATERIAL OF HAROLD PINTER'S WORKS)}

Actuality. The world of mind and senses in the worldview paradigm had a meeting with one of the utterances of the German writer Johann Goethe, who is the author of important maxim essence which states that acquisition of plenitude (all) for an individual, history, time, languages is impossible without passing of the state of «nothing».

Purpose. To show absurdity as a philosophical platform «Meeting-Event» which has a traumatic orientation, where heroes, their dialogues are only a background, linguistic «lace», creating the cocoon of fate for the characters.

Methods. The literary treasury of contemporaneity represents the symbolic measuring of language: from the technique of uttering to the event description of the linguistic stratification which takes place due to the ability of piling up of many semantic loadings in linguistic constructions (Jacques Lacquer, Roland Barthes, Jean-Paul Sartre).

Research results. There is no the realized beginning and end in literary works by $H$. Pinter. In fact, an end can become a prologue or the beginning to the touch with reality; the hidden reveals the real, and reality accompanies the initiate space with its presence, due to development of the performance - reality. The individual collides with himself, and, due to Nothing, realizes the essence, no matter how humiliating or irreproachable it would be. This meeting is absurd by its nature, however simultaneously it creates alternative senses, though it contains the core of the trauma. The rotation around these states ("plenitude and nothing») forms and demonstrates creative literary works by English writer Harold Pinter, one of the Nobel laureates.

The address to the emptiness, that is deeper and more complete than the most gap-filling maintenance of thing, the possibility to join in the discussion and the search for the sources of the personal oblivion through opening of charms of fragmentation, mosaic life of the heroes, are the basics of the plot crossings in the works of the writer ("Watch», "Treason» and other).

Key words: absurdity, Nothing, symbolic life, sense, linguistic construction. 